\title{
Welfare Policy and Social Transfers in Croatia
}

Bejaković, Predrag; McAuley, Alastair

Source / Izvornik: Occasional Paper Series, 1999, 3, 1 - 35

Journal article, Published version

Rad u časopisu, Objavljena verzija rada (izdavačev PDF)

https://doi.org/10.3326/ops.8

Permanent link / Trajna poveznica: https://urn.nsk.hr/urn:nbn:hr:242:512004

Rights / Prava: Attribution-NonCommercial-NoDerivatives 4.0 International/ImenovanjeNekomercijalno-Bez prerada 4.0 međunarodna

Download date / Datum preuzimanja: 2023-04-26

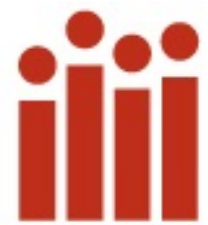

Repository / Repozitorij:

Institute of Public Finance Repository

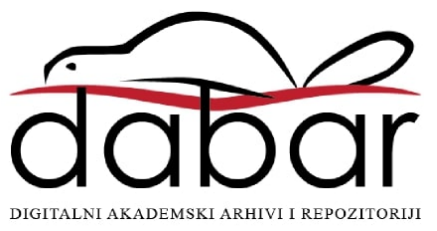




\title{
WELFARE POLICY AND SOCIAL TRANSFERS IN CROATIA
}

Predrag Bejaković \& Alastair McAuley

Occasional Paper No. 8

July 1999

\author{
Institute of Public Finance \\ Katančićeva 5, 10000 Zagreb \\ CROATIA \\ tel: +38514819363 \\ fax: +38514819365 \\ e-mail: ured@ijf.hr \\ C Institute of Public Finance 1999
}




\section{WELFARE POLICY AND SOCIAL TRANSFERS IN CROATIA}

Predrag Bejaković \& Alastair McAuley

This Occasional Paper occurred as the byproduct of preparations for writing the report by Predrag Bejaković and Alastair McAuley "Welfare Policy and Social Transfers in the Republic of Croatia", The World Bank, Europe and Central Asia Region, Poverty Reduction and Economic Management Unit, June 1998.

The authors, Predrag Bejaković (Institute of Public Finance, Zagreb, Croatia) and Alastair McAuley (University of Essex, Colchester, England) first published the text in Croatian in the Institute's journal "Financijska praksa", Volume 23, Number 1, (March 1999). This Occasional Paper is the English language translation of the article published in "Financijska praksa". 


ABSTRACT
$\begin{aligned} & \text { The purpose of this paper is to review the range of social policies that have been adopted by the } \\ & \text { government of Croatia since independence together with those that have been retained from the } \\ & \text { socialist past and to ask whether it might be possible to improve them. The paper concentrates on } \\ & \text { issues of social security and employment. After the Introduction, in Section } 2 \text { we provide estimates } \\ & \text { of the level and composition of social expenditure in Croatia in the last two or three years. These } \\ & \text { show that the scale of public expenditure has been growing and that it is high compared with a } \\ & \text { number of other transition economies. This is also true of social expenditure within the overall } \\ & \text { budget. It is this development that has, in fact, prompted the present report. Section } 3 \text { focuses upon } \\ & \text { the labour market. It assesses evidence on participation and on the level of unemployment. It also } \\ & \text { examines evidence on inequality and poverty. Finally, it looks at the unemployment benefit to see } \\ & \text { how far it provides an adequate safety-net for those who lose their jobs. Section } 4 \text { concentrates on the } \\ & \text { structure of social welfare and social assistance programmes provided by the Croatian government. } \\ & \text { Finally, Section } 5 \text { examines possible ways in which the efficacy of the present system might be } \\ & \text { improved. }\end{aligned}$




\section{WELFARE POLICY AND SOCIAL TRANSFERS \\ IN CROATIA}

\section{Introduction}

The purpose of this paper is to review the range of social policies that have been adopted by the government of Croatia since independence together with those that have been retained from the socialist past and to ask whether it might be possible to improve them $\square$ The report concentrates on issues of social security and employment since other specialists commissioned by the World Bank are considering the questions of pension reform and the reform of health insurance.

The government of Croatia faces a wider range of social challenges than those of most other postsocialist states. In common with most of Eastern Europe, it has to cope with the consequences of the so-called transition recession, with economic restructuring and privatisation. In addition, it has to complete the process of state-building since it was a part of the Yugoslav Federation until 1992 and it has had to cope with the consequences of the war with Serbia. These include the repair of war damage and the resettlement of refugees and displaced persons. Finally, in the wake of the Dayton Accords and the return of previously occupied territory, it has had to return its armed forces to a peacetime footing and reintegrate its war veterans into civil society. These additional tasks have placed an added burden on the social welfare institutions at various levels. At the same time they make it all the more important that available resources are used efficiently if the government is to make sufficient space for economic growth upon which the long-term solution of these social problems depends.

The analysis of social policy in Croatia is hindered by the lack of certain statistics and by inconsistencies in some of what is published. The most important lacuna for the purposes of this report is the absence of a Family Budget Survey (FBS) — which has not been carried out since 1987. This gap should, however, soon be filled: a decision has been taken to conduct such a survey and the first results from it are promised for the end of 1998. Second, the absence of an FBS makes it more difficult to calculate a cost of living index for particular population groups; as a result, indexes of real wages tend to be calculated using the retail price index. Third, there are substantial divergences between estimates of employment and unemployment derived from the Labour Force

\footnotetext{
${ }^{1}$ P. Bejaković and A. McAuley thank Dubravka Jurlina-Alibegović, Sandra Švaljek, Katarina Ott, Sanja Crnković-Pozaić, Živko Jurčević, Vlado Puljiz, Geoff Dixon and Jean-Jacques Dethier for useful remarks and suggestions.
} 
Survey (which attempts to employ a methodology consistent with that recommended by the ILO) and those which are generated by the Employment Service - that is by registration data.

As a separate issue, the government of Croatia has so far declined to adopt an official poverty lineon the grounds, it appears, that in present circumstances it can make no commitment to ensure that no one will be forced to survive in poverty. This means that all estimates of the scale of poverty in Croatia - and hence on the need for particular forms of social assistance-are unofficial. The government does, however specify a so-called subsistence minimum (which is thought to be significantly below a reasonable poverty line) and this plays an important role in the determination of levels of social assistance.

Despite the scale and complexity of the social problems facing the government of Croatia, the evidence suggests that its economic policies have been reasonably successful. Between 1990 and 1993 real gross domestic product fell by some 27 percent; since then, growth has resumed. In 1997 the rate of growth was as high as 4.5 percent; output is now some 80 percent of its level in 1990 Furthermore, there is some evidence to suggest that even industrial output has begun to increase. Also, after suffering from very high inflation in the early $1990 \mathrm{~s}$, the government introduced a successful stabilisation programme. As a result, in the last two or three years inflation has remained low; in 1997, the retail price index increased by as little as 3.6 percent 5 Further, in 1997 the budget deficit was only 1.6 percent of GDP, much lower than expected.

There are, however, some worrying aspects of the economy's recent performance-chief among them is the balance of payments deficit. Second, as we shall report in greater detail below, unemployment remains high — although not as high as suggested by official statistics. According to the Labour Force Survey it was approximately 10 percent in 1997. Finally, the share of the second economy appears to be very large. A recent study undertaken by the Institute of Public Finance, estimated that "...the unofficial economy in the Republic of Croatia was probably at least 25 percent of GDP in 1995.' difficult to undertake the social welfare programmes to which the government is committed.

The rest of this report is organised as follows. In section 2 we provide estimates of the level and composition of social expenditure in Croatia in the last two or three years. These show that the scale

\footnotetext{
2 Croatia: Beyond Stabilisation World Bank, Washington DC, 1997; p. 110. Croatian Economic Monitor PlanEcon Report No. 7-8, 1998; p. 3.

${ }^{3}$ There was, however, a sharp spike in the RPI in January 1998 when the new VAT was introduced. Croatian Economic Monitor PlanEcon Report No. 7-8, 1998; p. 3.

${ }^{4}$ Ivo Bičanić \& Katarina Ott The Unofficial Economy in Croatia: Ccauses, Size and Consequences Occasional Paper No. 3 Institute of Public Finance, Zagreb, 1997; p. 1.
} 
of public expenditure has been growing and that it is high compared with a number of other transition economies. This is also true of social expenditure within the overall budget. It is this development that has, in fact, prompted the present report. Section 3 focuses upon the labour market. It assesses evidence on participation and on the level of unemployment. It also examines evidence on inequality and poverty. Finally, it looks at the unemployment benefit to see how far it provides an adequate safety-net for those who lose their jobs. Section 4 concentrates on the structure of social welfare and social assistance programmes provided by the Croatian government and finally, Section 5 examines possible ways in which the efficacy of the present system might be improved.

\section{Social Expenditure and the Fiscal Burden}

It appears that both the level of public expenditure as a share of GDP and the proportion of public expenditure devoted to broadly social policy objectives in Croatia is high — and has been rising in the past two or three years. These trends, if continued, threaten to undermine the reconstruction and development strategy adopted by the government (and described, inter alia, in the World Bank's CEM Croatia: Beyond Stabilisation In this section the evidence demonstrating the existence of these adverse trends in public expenditure is presented. The sources of public revenue are also analysed. This material provides a framework for the analysis of employment, unemployment and social assistance in Sections 3 and 4.

Public expenditure in Croatia is undertaken by the national government and by local authorities at County (Županija), city and municipal levels — and recorded in the budgets of these organisations. It is also undertaken by public authorities like the Pension and Health Fund. These organisations are "off-budget" in the sense that neither their revenues nor their expenditures form part of the national government's budget. They are not, however, independent or autonomous; the government accepts responsibility for making good any shortfall in funding that might occur. We believe that it would be helpful both for planning and for accountability if the Ministry of Finance (or the Statistical Office) prepared information about the level and composition of expenditure for the general government broadly defined on a consolidated basis.

Meanwhile, in Table 10 we present information on volume of public expenditure (in an unconsolidated form) from the various institutions and levels of government for the years 19951998. The figures show that public expenditure in this sense amounted to some 50.8 billion kunas in

\footnotetext{
${ }^{5}$ Croatia: Beyond Stabilisation (Report No. 17261-HR) World Bank, Washington, DC, 19 December 1997.

${ }^{6}$ The Tables are placed at the end of the paper.
} 
1995; this was equal to almost 56 percent of GDP. By 1997, public expenditure had increased to 68 billion kunas—or almost 62 percent of GDP.

Further analysis of the figures suggests that although the national government was responsible for public expenditure amounting to some 30 percent of GDP in 1995, it has not presided over a major expansion in the last two or three years: in 1997, the expenditure out of the national budget amounted to little more than 31 percent of GDP. Over the same period, expenditure by extrabudgetary funds has increased from 19 percent of GDP to as much as 23.2 percent (and expenditure out of county, city and municipal budgets has increased from 4.7 percent to as much as 7.3 percent of GDP.)

As the figures in Table 1 show, the largest of the funds is the Pension Fund; it is responsible for approximately half of all public expenditure out of extra-budgetary sources. Its dominance has tended to increase over the last two or three years since it has also grown rapidly $\square$ This growth underlines the importance of the proposed reform of the pension system. Expenditure out of each of these Funds increased by more than sixty percent in nominal terms between 1995 and 1997.

In Tables 2 and 3 we present estimates of the composition of social expenditure - but only out of central and local government budgets. Expenditures by various extra-budgetary funds are ignored. The figures in Table 2 repeat the story told in Table 1: over the years covered by the table, expenditure on social policy areas (health-care, education and social welfare) increased 7.3 billion kunas to 11.9 billion kunas. Expenditure on housing and communal services also increased sharply in nominal terms - from 2.3 billion to almost 4.5 billion kunas. This increase meant that the share of social expenditure in the budget increased from 22.3 percent to as much as 28.1 percent. The share of total budgetary expenditure on housing also increased sharply between 1995 and 1996; but it fell slightly between 1996 and 1997.

As the figures in Table 3 show, in 1997, the national government was responsible for more than four fifths of total public expenditure; the bulk of the rest was undertaken by city and municipal authorities. Second, social policy-related expenditure accounted for almost a third of the total expenditure of the national government; it was much less important at sub-national levels. Cities were responsible for the bulk of expenditure on housing and communal services; they were also

\footnotetext{
${ }^{7}$ As part of its stabilisation programme, the government of Croatia modified the procedure by which pensions were indexed to earnings and the cost of living. As a result, the replacement ratio fell after 1994. This caused pensioner groups to turn to the courts in an attempt to force the government to restore the previous link to earnings. In May 1998, the Constitutional Court ruled in their favour. This decision means that levels of expenditure on pensions - and hence their share in total public expenditure - is likely to increase further. This increase could be substantial since the court suggested that compensation should be back-dated to 1994 .
} 
responsible for a significant proportion of expenditure on education. The national government, on the other hand, was responsible for most expenditure linked to social security and welfare. This is one of two areas upon which this Report focuses.

Table 4 brings out another feature of Croatia's public finances: its very heavy reliance on payroll deductions to finance social programmes - and general government activity more generally. In 1997, direct taxes provided some 48 percent of central government's tax revenues. Of this total, payroll deductions (taxes and contributions) accounted for more than 37 percent, while personal income tax accounted for less than seven percent. Corporate income tax accounted for even less: only just over three percent. Indirect taxes on domestic activities-primarily the sales taxaccounted for a little more than two fifths of the total.

In 1998, as already mentioned, the sales tax has been replaced by VAT. The changeover has been surprisingly successful - in the first quarter at least - and collections are substantially above prediction. It has been suggested that some part of the payroll deductions might be abolished - and the cost of the services they pay for be transferred to the general budget. It might be worth going further and substituting the personal income tax (or, possibly, the personal and the corporate income tax) for deductions from the wage fund. Such a change would have two possible advantages: it would reduce the indirect costs of labour and thus might encourage entrepreneurs to employ more labour. It would also make it more likely that such employment would be in the first rather than the second economy. Second, it would mean that the burden of paying for social services would be spread more equitably, since the personal income tax falls on all income, rather than just on wages Income tax is also at least mildly progressive whereas payroll deductions are proportional at best.

The high and rising levels of social expenditure in Croatia, it has been claimed, are a consequence of the large numbers of persons dependent upon state assistance. These include pensioners, the unemployed and, more generally, the inactive. Containment of the rising volume of cash transfers depends upon improvements in the labour market. This topic is taken up in the next section.

\section{The Labour Market: employment, unemployment and earnings}

\section{Employment and unemployment}

\footnotetext{
8 For reasons that are not wholly clear, it appears that the new VAT has succeeded in capturing some of the transactions that were previously in the hidden economy.

${ }^{9}$ Almost uniquely, the Croatian income tax is in fact an expenditure tax since interest on savings is tax free.
} 
The labour market plays a crucial role in determining the living standards of individual Croatiansand hence the nature and extent of demands faced by social policy institutions. A flexible labour market, together with a growing economy, can ensure high rates of employment and rising wages. This will reduce the strain on the social assistance system; it will reduce the numbers seeking to retire early and so on. An inflexible labour market and restrictions on the mobility of labour will accentuate problems of poverty and social exclusion and thus add to the burden of social care associated with recession. It will also make it harder to restructure the economy. This section examines the performance of the labour market in Croatia; in particular, we consider participation rates and the level of unemployment. We also discuss the main objectives of national employment policy. Second, we examine available evidence on recent changes in the cost of living and the scale of poverty, on the evolution of real wages and the levels of unemployment benefit. This analysis complements the review of social assistance and social welfare programmes contained in the next section.

There are two sources of statistical information about employment and unemployment in Croatia. There are statistics produced as a by-product of the administrative activities of the Employment Service. Second, in 1996 and 1997, the State Statistical Service also undertook a labour force survey (LFS). This was carried out, it is claimed “...in compliance with methodological rules and guidelines of the ILO...and the European Statistical Office (Eurostat) which [ensures] methodological comparability [with] surveys in EU countries.'T0 For most purposes, LFS data is more reliable than that produced by the Employment Service.

Table 5 provides an overview of the state of the labour market in Croatia in 1996-97—or, at least, in those areas covered by the labour force survey. It reports a population of 3.7 million in 1996. This is some 742,000 less than the estimate reported in Croatia: Beyond Stabilisation which supposedly covers the whole territory of the country. It also suggests that persons under the age of fifteen years made up some 18.8 percent of the total population whereas Croatia: Beyond Stabilisation suggests a slightly higher proportion-19.6 percent. Finally, the LFS suggests that males make up some 47.8 percent of the total population while the alternative source suggests a higher figure of 48.4 percent. ${ }^{[2}$

\footnotetext{
${ }^{10}$ Priopćenje Državnog Zavoda za Statistiku Republike Hrvatske, 12. 2. 1998; p. 14.

${ }^{11}$ The Surveys were carried out in November 1996 and June 1997. That in 1997 involved interviews with 10,434 households (26,368 individuals). The sample was stratified, two-stage and randomly chosen. But the sampling frame excluded those areas which were liberated in 1995 or were still occupied in 1996.

${ }^{12}$ Croatia: Beyond Stabilisation World Bank, Washington, DC, 1997; p. 104. These differences are probably too large to be explained by sampling variance; more likely, the demographic structure of the excluded areas differs from that of the rest of the country.
} 
Unusually, the LFS treats the population of working age as those over the age of fifteen year, because a significant number of the employed are over the age of 65 years. Table 5 shows that, using these definitions, approximately 56 percent of the population of working age was economically active in 1996; in 1997, this proportion had fallen to 54.6 percent. Not surprisingly, activity rates were higher among males than females; but, worryingly, these rates fell for both sexes between 1996 and 1997.

Age- and sex-specific activity rates are reported in Table 6. These show that participation rates are much higher then employment rates for both sexes among those under the age of 25 . This is partly a reflection of continuing education and partly of relatively high rates of youth unemployment. Second, the table shows that some sixteen percent of men and almost ten percent of women between the ages of 65 and 85 remain in employment. On the other hand, the table also reports almost a half of men aged between 50 and 65 years were no longer economically active. Almost three quarters of women in the same age group had ceased to work or to look for work as well. These figures are consistent with a situation where a significant proportion of the labour force in the relevant age group has taken early retirement. This is in addition to the fact that the official retirement age in Croatia (sixty for men and fifty-five for women) is low by the standards of market economiesalthough not out of line with the position in other transition economies. This pattern of early retirement must raise dependency ratios and put additional strain on the pension system.

Table 7 reports estimates of age-and sex-specific unemployment rates for 1997 derived from the Labour Force Survey. These show that, in that year, the unemployment rate among men was 9.5 percent. Among women it was somewhat higher - 10.4 percent. Combining these two figures yields an estimate of the unemployment rate of 9.9 percent. This is marginally lower than the rate in 1996 which was 10 percent. Both these figures differ from the estimate derived from registration data15.7 percent in 1996 and 16.5 percent in 1997. Furthermore, not only are the estimates based on administrative sources more than fifty percent higher than those from the LFS, the two sources imply divergent trends. The problem is that the unemployment register is contaminated by the fact that it contains many individuals who are required to register if they wish to be covered by government health insurance, but who are not actively seeking work—or are not available for work $\square$ They should not, therefore be classified as unemployed; they are, rather, economically inactive.

The figures in Table 7 also show that almost 30 percent of males between the ages of 15 and 25 years and more than a quarter of females in the same age group are unemployed. These unemployment rates are between three and four times as high as those among the population of

${ }^{13}$ National Employment Policy Government of the Republic of Croatia, Zagreb, February, 1998; p. 13. 
prime working age; they are more than six times as high as those among whom early retirement is a practical alternative. Youth unemployment is a serious problem and it is important that policies are devised to encourage young people to seek employment—and employers to offer them jobs. But it is important to put the problem in its proper perspective. As the second panel of Table 7 shows, despite the very much higher unemployment rates, young people only made up slightly over a third of the pool of the unemployed. 54.3 percent of the unemployed - more than half-were between the ages of 25 and 50 years old. Policies to reduce the level of unemployment should not be focused too narrowly upon the problem of youth unemployment.

Table 8 reports on the duration of unemployment in Croatia — as revealed by the LFS. It shows that more than two fifths of those classified as unemployed have been out of work for at least a yearand that more than a quarter have been out of work for two years. Second, the Table shows that almost a third of unemployed women have been out of work for more than two years as compared with little more than a fifth of unemployed men. As a result, women make up 55 percent of the long-term unemployed although they only account for 48 percent of total unemployment.

Official figures suggest that there has been a steady decline in employment since the early 1990s. In 1990 total employment was reported as 1.6 million; in 1996 it had fallen to as little as 1.2 million There is no reason to believe that this trend has been reversed in the last two years. The level of employment reported from these sources is significantly less than that derived from the Labour Force Survey, but there is no reason to reject the claim that employment has fallen. implications. First, high levels of employment are the best way to ensure a satisfactory standard of living for the mass of the population, so recent developments suggest that an increasing proportion of the population may find itself under threat. Second, since it is from the earnings of those employed that the authorities acquire the resources they use to provide social assistance, a decline implies that either less will be available — or that the burden on the employed will increase. It is, therefore of some importance to reverse this trend and this is a primary objective of national employment policy.

\footnotetext{
${ }^{14}$ Another thing to note about the figures in Table 7 is that although the unemployment rate among women is slightly higher than that among men, the latter make up a larger proportion of the stock of unemployed persons. This is an example of the difference between risk and incidence. If policy is intended to reduce the prevalence of a particular condition it should concentrate on those groups which account for the largest numbers of persons who suffer from it - even if it is relatively uncommon. On the other hand, if policy is intended to minimise the cost of eliminating the condition, it should focus upon those groups at greatest risk of suffering from the condition.

${ }^{15}$ Croatia: Beyond Stabilisation World Bank, Washington DC, p. 106.

${ }^{16}$ See the analysis in Human Development Report: Croatia UNHDP, Zagreb, 1997; pp. 16-18.
} 
The Croatian labour market is characterised by substantial unemployment and, it is suggested by relatively low levels of utilisation of the labour that is employed. This is confirmed by data on hours of work reported in the Labour Force Survey $\square$ But, as we have already seen, there is a large informal sector. Transition has resulted in a significant shift of labour from the formal sector to jobs in agriculture, trade, construction and services, often in the informal sector. While some of this shift has been desirable — in that it has been in response to the pattern of consumer demand - there is little to suggest that it has resulted in improved average labour productivity in the economy as a whole Furthermore, it has been claimed that jobs in the informal sector in general pay lower wages than in the formal one $\square$ and pay them more irregularly. Finally, this shift narrows the fiscal base since informal sector employers do not pay payroll taxes and contributions - or pay them at minimum rates.

This analysis has led to the articulation of one objective of national employment policy: the legitimisation of the informal sector. It is desirable that jobs (and, more generally economic activity) currently located in the so-called hidden economy be brought back into the formal, regulated economy - and thus become subject to taxation. This implies a re-examination of the factors that caused the shift to the informal sector in recent years. It also implies a commitment to the creation of more equal opportunities for the self-employed population (and those employed by them) to enable them to make a better living from their work.

Both the low level of job creation in the formal sector and the shift to the informal one have been attributed to the high indirect cost of employment - and, in particular, to the government's heavy reliance on payroll deductions. The National Employment Policy document proposes various changes with the aim of reducing the aggregate level of deductions from 44.2 percent to 35.7 percent of a firm's wage bill[2]We would like to point out, however, that a deduction rate of 35-36 percent is still higher than the average for OECD countries and towards the upper end of the range for transition economies as well. We believe that a major effort should be made to reduce the aggregate deduction rate further-say to $20-25$ percent, the lower end of the range found among OECD countries - even if this implies some reduction in the range or standard of social support

\footnotetext{
17 With the exception the self-employed who employ others (who reportedly work an average of 50 hours a week) men worked 42-43 hours a week in 1997; women worked slightly less - in paid employment. Unpaid family members worked as little as 37 hours a week on average. Priopćenje Državnog Zavoda za Statistiku Republike Hrvatske 12. 2. 1998; p. 12

${ }^{18}$ National Employment Policy Government of the Republic of Croatia, Zagreb, February, 1998; p. 5.

${ }^{19}$ Or rather, that those who have shifted to the informal sector often earn less than they had, previously in the formal sector.

${ }^{20}$ National Employment Policy Government of the Republic of Croatia, Zagreb, February, 1998; p. 5.

21 National Employment Policy Government of the Republic of Croatia, Zagreb, February, 1998; p. 11, 17. In particular it is proposed to abolish both the child benefit and the Public Water Fund deductions and to reduce pension and health insurance contributions.
} 
provided. The adverse consequences of such a reduction would, of course, be less if formal sector employment were increased.

The National Employment Policy document also stresses the desirability of undertaking a range of active labour market policy measures. It is suggested that that the labour force is underqualified - or perhaps wrongly qualified — for the demands of a market economy. This implies that effort should be put into training and retraining. Investment in human capital is desirable, but it is unlikely to produce results quickly. Moreover, it should probably concentrate on those under the age of 25 years. It is also suggested that the labour force is insufficiently mobile and that more resources should be committed to facilitating job-search (with the intention of increasing the number of matches.)

The National Employment Policy document also suggests a change to the procedure by which the right to health insurance, child and other welfare benefits are established. At present, university graduates, those released from prison or health-care institutions are required to register with the employment service in order to qualify for health insurance cover whether or not they are actively seeking or are available for work. Similarly, beneficiaries must register with the employment service in order to receive child allowances or certain other benefits even though many such persons are not actively seeking work-and some may be disabled. Such a procedure means that the so-called unemployment register contains many individuals who are not unemployed in terms of ILO definitions. This distracts the attention of those who work in the employment service from what should be their primary responsibility - the implementation of active and passive labour market activities. It also means that information derived from the register may be a misleading guide to policy.

The document proposes that decisions over entitlement to health insurance should no longer be the responsibility of the Croatian Employment Service. More radically, it also suggests that the funding of health insurance for particular categories of the population should be provided from sources other than payroll deductions If the proposals are adopted, registration with the employment service will be motivated by a wish to work - and those registered will correspond more closely to the ILO definition of unemployment. Furthermore, the change will allow the staff of the employment service to concentrate on the implementation of specifically labour market policies with an expected improvement in the service's effectiveness.

\footnotetext{
22 This would have the benefit that health insurance deduction rates could be reduced, making it easier to reduce indirect labour costs - and thus increase the likelihood that formal employment will increase.
} 


\section{Earnings}

If employment or the lack of it is one way in which the operation of the labour market impinges on the need for social assistance, then the other is in the level of wages that employment generates. In many countries, low (and irregular) pay is an important cause of poverty. Here we examine three issues connected with pay. First we assess available estimates of the poverty line or the cost of minimum subsistence. (For non-Croatians, this is important as it gives an indication of what the kuna is worth - and hence of the scale of the phenomenon of low pay.) Second, we report some of the available evidence about the evolution of real wages and wage inequality. (In the absence of a family budget survey or other information this is the nearest one can come to information about the distribution of income.) Finally, we describe the unemployment benefit system and attempt to assess how well it protects the unemployed.

Before turning to these issues, however, it is worth pointing out that there is very little statistical information available on any of them. The government of Croatia has not published an official poverty line. In the absence of a family budget survey, it cannot determine the weights needed to calculate a cost of living index - and does not in fact publish one. Data on wages are largely confined to the state sector; earnings in the private sector are badly observed. And, of course, without a family budget survey there are no estimates of the level or composition of family income - or of its distribution. All of this should be borne in mind in assessing the analysis that follows.

As has already been mentioned, the government of Croatia has not chosen to calculate an official poverty level. Some conception of the official idea of the minimum cost of subsistence may be derived, however, from the so-called subsistence minimum (SM) the social assistance payable to households without alternative means of support. The way that this has evolved--in nominal terms-is reported in Table 9. Until the end of 1997, the subsistence minimum only depended on family size. The implicit equivalence scale allowed 0.78 for the second member of a household, 0.67 for the third member and so on. In the new law on welfare a different principle was introduced: the amount allowed was made to depend upon age such that children between 15 and 18 years of age received the same as the first adult, those under the age of 7 years of age received the same as the second (and subsequent) adults -0.8 and children between the ages of 7 and 15 years received 0.9 of the single person's allowance. As a result, in 1998, the allowance paid for a family of four varies between 1190 kuna and 1400 kunas per month depending upon its demographic composition. 
This sum is much less than the minimum cost of living, egzistencijalni minimum, (EM) for a 4member worker's family calculated by the Croatian Council of Autonomous Trade Unions. In March-April 1998 this was estimated to be 4818 kuna. The EM is calculated according to what appears to be an appropriate methodology. A basket of consumers' goods is priced each month in a range of outlets in different parts of the country. The results are used to calculate a minimum cost of living for an (urban) family of four. In April 1998 this was made up as follows:

\begin{tabular}{lcr} 
Category & Expenditure (kunas) & Weight in Index (\%) \\
\hline Foodstuffs & 1920.41 & 39.8 \\
Housing etc. & 1311.85 & 27.2 \\
Clothes and Footwear & 643.78 & 13.4 \\
Education and Culture & 374.41 & 7.8 \\
Transport & 315.00 & 6.5 \\
Hygiene & 251.09 & 5.2 \\
Total & 4818.54 & 100.0
\end{tabular}

Without going too deeply into the content of the consumption basket underlying this index, the above figures suggest that the standard aimed at is too high. At subsistence--or, more properly, at the poverty line in a country with a GDP similar to that of Croatia one would have expected food to occupy more than 40 percent of total expenditure and housing (and transport) to take up less. This reservation is reinforced by the observation that the "basket" assumes that the family possesses a car, that it is purchasing a two-room apartment of $50 \mathrm{~m}^{2}$ with central heating and, less surprisingly, that it possesses both television and a telephone. All of this suggests that the Union's EM would afford a standard of living somewhat above the austere.

In addition, the trade union index suggests that the cost of living is increasing much more rapidly than the retail price index. Indeed, it is clamed that the EM has increased by at least 22 percent in the past six months at a time when the RPI is reported to have increased in 1997 by less than 4 percent. Such a divergence is barely plausible and it suggests that there are shortcomings in the way in which the index is calculated--despite the apparent soundness of the methodology.

A third approach to the calculation of a notional poverty line is to derive it from the distribution of income--that is to postulate a relative poverty line at, say two thirds of median income. This approach is made difficult by the absence of data on the distribution of income. In April 1998 median earnings were 2252 kunas a month; assuming 1.7 employed persons per family implies a median family income from employment of 3830 kunas and, allowing 20 percent for income from 
other sources a notional median family income of 4596 kunas a month. Three fifths of this would imply a poverty line for a family of four of 2760 kunas. This is a little less than 60 percent of the EM but almost double the MS. Having established a series of benchmarks for the assessment of poverty in Croatia, we now turn to an assessment of the evolution of earnings and inequality.

The evolution of nominal and real wages since the middle of 1995 is reported in Table 10. The figures show a steady increase in both nominal and real wages. Over the period covered by the table, real wages increased by some 23.6 percent, or at some 9 percent a year. This shows that steady progress has been made in overcoming the consequences of war and transitional recessioneven though there is still some way to go before the economy (and average wages) recover their prewar level.

Table 11 provides some information about changes in the distribution of earnings - or rather wages. The distributions from which the measures of location and dispersion have been derived probably refer to the same "enterprise sector" as those in Table 10. They probably therefore under-represent the private sector and hence the scale of inequality. But taking them at face value, they suggest that the sharp growth in inequality, so characteristic of transition economies has ceased-and has even been reversed since 199323 Furthermore, some progress has been made in tackling the problem of low pay. Rutkowski reports that in 1993, some 19.7 percent of workers were earning less than two thirds of the median wage. According to the distribution underlying Table 11, in March 1998, only 15.5 percent of workers were in that situation.

The figures given in Tables 10 and 11 suggest that average real earnings have increased and that inequality has fallen since 1995. Taken together these suggest that poverty will not have increased - at least among the employed population. Since, according to the Labour Force Survey, unemployment did not increase between 1996 and 1997 (indeed, it fell marginally) there is unlikely to have been a sharp increase in the numbers in poverty on this account. On the other hand, the participation rate fell between 1996 and 1997 (by almost 2 percentage points.) That is, the proportion of the population that was inactive increased. This may reflect increased affluence but it is more likely to be a consequence of the so-called discouraged worker effect and, possibly some part of the shift from formal to informal sector employment. As such, certainly as concerns the first of these components, it is consistent with some increase in poverty. How far this is the case will

23 Rutkowski has described the growth in inequality of earnings during transition. His figures indicate that, in Croatia, the ratio of ninth to first deciles in 1987 was 2.59 ; by 1993, this had increased to 4.36 . So far as I can tell, he was using the same series on wages as are used in Table 11. Yet, as the figures in Table 11 indicate, the decile ratio had fallen to 2.6 in 1996. See Jan Rutkowski Changes in Wage Structure During Economic Transition in Central and Eastern Europe World Bank Technical Paper No. 340 (Social Challenges of Transition Series) Washington, DC, 1996. 
depend on the extent to which unemployment benefit constitutes a safety net which protects those who have withdrawn from the work.

The rights of unemployed persons are set out in the Employment Act of 1996. This states that workers who are discharged are entitled to retain their health and disability insurance, to preserve their pension rights and to continue to receive child benefits. In addition, subject to certain conditions they are entitled to receive unemployment compensation. They may also benefit from active employment policy measures undertaken by the Employment Service.

The Employment Act states that unemployed persons are entitled to receive compensation if they have worked continuously for the past nine months - or for at least twelve out of the previous eighteen months. Depending on how long they have worked, unemployed persons may receive benefit for between 78 and 312 days. (Before the new act was introduced, the benefit period was as long as 468 days.) The amount of benefit depends upon wage or salary received for full-time work in the three months preceding the onset of unemployment. For the first 78 days benefit is paid at a rate equal to 80 percent of previous wage or salary; for the rest of the period, it is set at sixty percent. ${ }^{4}$ Notwithstanding the above formula, unemployment compensation cannot be less than 20 percent of the average wage for the economy as a whole (as determined by the latest published figures.) Nor can it exceed a figure determined from time to time by the Minister of Labour and Social Welfare in agreement with the minister of Finance.

Women with a child under one year old who lose their jobs continue to receive unemployment benefit until the child's first birthday - irrespective of the formula given above. Women with twins or with three or more children - at least one of which is under the age of three years - will also receive compensation until the child's third birthday.

According the Article 19 of the Employment Law, workers are not entitled to receive benefit in the following circumstances: if they left work of their own accord; if they failed to achieve the required standard of performance during a period of probation or if they lost their job after having failed to pass a professional examination; if they failed to qualify after an apprenticeship; if they were dismissed for a breach of labour discipline. Workers are also not entitled to unemployment compensation if they are dismissed for absenteeism - for being absent for five or more consecutive days without adequate reason. Finally, they are not entitled to receive unemployment benefit if they are dismissed as a result of receiving a prison sentence of more than six months duration. Workers

\footnotetext{
${ }^{24}$ Before the new law was adopted, unemployment compensation was equal to 50 percent of the worker's average salary for the three months preceding the loss of a job.
} 
who are disabled (as a result of an industrial injury or occupational disease) are not entitled to unemployment benefit; nor are those who retire—or meet the conditions for retirement.

Unemployment benefit will be withdrawn if a worker reaches retirement age and fulfils the requirements for the receipt of an old-age pension. It will also be withdrawn if the beneficiary fails to visit the Employment Agency when requested to do so; if he or she refuses to accept the first job offered that is appropriate to his professional skill or qualifications.

In January 1997, the lowest unemployment benefit payable was 415 kunas; by September this had risen to 479.2 kunas. For the whole of 1997, the highest level of benefit was set at 900 kunas. These sums are higher than the SM for a single person but less than the relative poverty line (2760 kunas for a family of four) and much less than the EM proposed by the Trade Union. It is generally believed that they are insufficient to keep recipients out of poverty-particularly if they have dependants.

Table 12 provides a little more information about the operation of the unemployment benefit programme. The first thing to note, however, is that registered unemployment in 1996 and 1997 is substantially larger than that estimated from the labour force survey-for 1997, a monthly average of 277,000 as compared with 175,000 . Second, in all three years only a small proportion of those registered are receiving benefit. In 1995 it was less than 15 percent; in 1997 it was almost a fifth. Third, the average monthly value of the benefit was 618 kunas in 1995 or, approximately one third of the average wage. In 1997 the average benefit had increased to 733 kunas; this was equal to some 31 percent of the average wage. Although in absolute value the unemployment compensation seems rather parsimonious, the implied replacement ratios do not seem to be substantially out of line with those encountered in other industrial economies. If unemployment benefit were much higher, it might begin to constitute a disincentive to active search — and hence reinforce whatever tendencies exist for the creation of an unemployment trap.

The analysis of this section has shown that there is a significant (and growing) inactive population a significant proportion of which is dependent on the state. It has also shown, however, that official unemployment figures are exaggerated. On the other hand, unemployment is a particularly acute problem among those between the ages of 15 and 25, between a quarter and a third of whom are without work. Long term unemployment is also substantial among women. In the past three years or so, average wages have increased and inequality has fallen — or, at least has not increased. The

\footnotetext{
${ }^{25}$ For more detail on this scheme see P. Bejaković Welfare Policy and Social Transfers in the Republic of Croatia (mimeo) Zagreb, April 1998; pp. 18-23.
} 
proportion of the labour force on low pay has fallen. These trends suggest that the problem of poverty has not increased among the employed population. But it may be extensive-particularly among those whose connection with the labour market is tenuous or non-existent. Just how the welfare system deals with this group and with other social problems is discussed in the next section.

\section{Social Welfare and Social Assistance}

The social welfare and social assistance programmes provided by the government of Croatia are in process of evolution. At independence, Croatia possessed a system of social security and social assistance that was substantially socialist; it was similar to those found in many other transition economies. It provided social protection through subsidies for basic wage goods; as we have seen, it promised a relatively young age of retirement; and it offered cash transfers to assist with such unexpected outlays as funerals and a layette for a baby. In the last five to seven years, however, this system has been progressively modified, both in response to financial stringency and to make the system more consistent with a market economy. The most recent step in this process has been the adoption of a new Law on Social Welfare which came into effect in January 1998. This law has reorganised (and somewhat simplified) the cash transfers offered by the Ministry of Labour and Social Welfare (MLSW). It has also simplified the forms of in-kind assistance provided by the state. But the introduction of the new law implies that virtually all the material about the operation of the system that we have obtained is obsolete: it refers to cash transfers or in-kind benefits that no longer exist. Furthermore there is no information yet available about the cost of various components of the new system; at best we know something about the number of beneficiaries.

This fact has affected the structure of this section. It is organised as follows: it begins with a brief review of the old system - indicating the range of transfers and in-kind benefits that used to be provided, how much they cost and how many beneficiaries were helped by each. Second, the new benefits and allowances provided by the Law on Social Welfare are described - as are those that appear to continue from the old system. Third, the system of child benefits is described, although this is under threat of substantial reform. The section ends with an assessment of the system as it presently exists.

\section{A review of the old system}

The Social Welfare system as it operated in Croatia between, say 1994 and the end of 1997 provided for both cash transfers and in-kind benefits. According to the statistics maintained by the MLSW there were some twelve different cash transfers and at least six types of in-kind assistance 
provided. In addition, some non-governmental organisations provided help for particular categories of needy families - refugees, displaced persons, the elderly and indigent and so on. In order to keep track of who was receiving what, the Ministry issued all beneficiaries with a so-called social card which on the one hand affirmed an individual or family's right to benefit and on the other was supposed to record all the forms of assistance which a particular family received. According to the MLSW, in March 1997 there were some 98.8 thousand social cards in circulation covering some 219.9 thousand individuals - members of families. As Table 14 below indicates, for 1997 as a whole there were some 336,000 beneficiaries of the system so it is possible that there was some duplication of pay-outs. The whole system of cards has now been abolished.

Tables 13 and 14 provide a basic overview of the Croatian social welfare system. It consists of three components: cash transfers, benefits in kind and a range of residential and foster-care programmes. The latter absorbed some seventy percent of total expenditure in 1997-although they assisted only 14 thousand individuals-less than five percent of all beneficiaries. They are thus expensiveparticularly residential care. It has been argued that fostering offers certain benefits over residential homes run by the state, particularly for children. We believe that these programmes would benefit from a more extensive (and more specialised) assessment than we were able to give them. Their economic costs should be assessed in conjunction with their social and psychological effects on those cared for; and alternatives to residential care should also be assessed.

Turning to the other two components of the welfare system: cash transfers are provided on a much larger scale than in-kind benefits although there are a relatively large number of recipients of the latter. In fact, this is misleading; by far the largest in-kind programme involves assistance in paying for public and communal services. This is classified as an "in-kind" benefit because the local welfare office pays the bills of those who receive help of this type directly. Hence it does not formally constitute a cash transfer. This approach probably reduces the temptation to spend such assistance on inappropriate commodities or services. But it reflects a relatively high degree of paternalism. It also makes it more difficult for recipient families to budget in a way that reflects their preferences. While they may be a case for making the cash payment payable to the wife rather than the husband, on balance this assistance should be transformed into a cash payment. The same is probably also true of distribution of clothes and foodstuffs - except insofar as they constitute emergency relief for displaced persons or refugees.

By far the greatest share of social assistance in Croatia in 1995-1997 took the form of cash transfers. The largest of these- both in terms of resources paid out and number of beneficiaries was the socalled subsidy for the social minimum. This involved payments to indigent households to bring their 
net income up to the social minimum. In 1997, the average payment per beneficiary under this scheme was approximately 212 kunas a month. It is interesting to note that the average payment made under the Financial Assistance Programme (which was intended for those without other means of support) was little higher-251 kunas per month. Payments under other programmes also appear to have been modest on the whole. Since the determination of entitlement involved assessment by social workers (who enjoyed a fair amount of discretion) it was probably quite costly to administer.

It has proved quite difficult to identify continuities in the system of benefits between that which was in operation before the end of 1997 and that which has been introduced under the new law. It appears that both permanent and temporary financial assistance and, possibly, the subsidy for the social minimum have been replaced by Assistance for Maintenance. Second, it is possible that the so-called financial assistance for the payment of bills for public and communal services has been replaced by the programme of assistance with accommodation costs. Third, a number of programmes continue, even though they are not mentioned explicitly in the new act. These include the Assistance for Work Training and Earning a Living, Assistance with Funeral Expenses and the Right to Reduced Working Time by Parents looking after Seriously Handicapped Children. It appears, however, that the programme providing financial assistance towards the purchase of layettes for single unemployed parents has been abolished. So, apparently, has the programme of financial assistance for the personal needs of beneficiaries.

\section{The new benefits and allowances}

The basic assistance programmes introduced by the new Law on Social Welfare are the so-called Assistance for Maintenance, the Assistance for Covering Accommodation Costs and the Nonrecurring Assistance. The act also reformulates the conditions for receiving an Allowance for Nursing and Home Care and makes provision for a range of residential care programmes.

The Assistance for Maintenance is intended for both individuals and families who have no resources and for those who have insufficient resources to reach the so-called subsistence minimum (SM). For most families, the scale of support is that described in Table 9. But additional provision is made for the disabled, for single and expectant mothers. (Article 16) Families can expect to receive the difference between their average income in the three months preceding that in which they make a claim and that which they would be entitled to according to the scale laid down in Table 9. In this context, income refers to earnings from all sources except disability payments, allowances for nursing and home care and assistance with accommodation costs. Alimony payments due to other persons are also subtracted from average income before entitlement is determined. Maintenance is 
not paid in respect of persons who are in the army, in prison or who have been in hospital for more than two months Before receiving assistance under the act, individuals are expected to realise major assets that they may own.

Assistance for Covering Accommodation Costs in the state sector is payable to an individual or family if their average income in the three months prior to the month in which a claim is made does not exceed 150 percent of the scale laid down in Table 9 (or Article 16 of the Act.) It is payable to those in private sector accommodation where income does not exceed 200 percent of the scale. Assistance is not payable if individuals or families own or co-own a second home. The amount payable shall equal the rent of the property occupied but for tenants in state property it cannot exceed one half of the scale figure given in Table 9. For tenants in private sector accommodation it cannot exceed the SM allowance given in Table 9 (or Article 16.)

Non-recurring Assistance is payable to those who due to current circumstances (birth of a child, death of a family member and so on) are not able to satisfy basic living requirements or particular needs. The amount paid shall equal what is needed to satisfy the particular purpose for which it is granted with the proviso that, if it exceeds three times the SM (presumably for an individual-350 kunas in 1998) the consent of the Ministry shall be obtained before a payment is made.

The act also makes provision for the distribution of in-kind assistance in the form of foodstuffs, clothes and footwear and so on in terms similar to those in operation in 1997 and earlier. It also provides for a variety of forms of institutional care. In this regard it states that the MLSW shall not provide such care to persons who can be assisted and looked after by family members, or if the care can be provided in another way.

Most if not all of the benefits provided for by the new act involve an income test of some kind. Applicants are required to provide social workers with information about all relevant forms of income and to communicate any substantial change in circumstances within eight days. Social workers enjoy considerable discretion in deciding whether to approve the payment of various forms of assistance. But, once granted, payments can continue for up to one year-unless beneficiaries inform the social work centre of changes in circumstances. The relevant Centre for Social Welfare is required periodically and at least once a year, to review the existence of facts and circumstances that were crucial for issuing the ruling about entitlement. The act does not lay down procedures or requirements for the verification of statements of resources. 
As has already been stated, in Croatia the Ministry of Labour and Social Welfare is not responsible for the payment of Child Allowances. Rather, these are funded by a special payroll deduction of 2.2 percent which is paid into an extra-budgetary fund. Child benefits are payable to the families of workers, pensioners and the unemployed, to the families of armed services personnel and those of military and civilian invalids. Recipients are entitled to support in respect of all children for whom they are responsible and as long as the children are in full-time education. The amount paid depends upon per-capita income in the household and varies from 103 kunas to 189 kunas a month for twoparent families and from 141 kunas to 276 kunas per month for single-parent families. It is not clear how the authorities determine the per-capita incomes of recipients; or how frequently the amount payable is adjusted. In 1996, the amounts received by the Child Benefit Fund (and basically used to pay child allowances) amounted to 0.9 percent of GDP.

A new law on child benefits is in preparation. One version of it envisages a considerable increase in the amount of the allowance in order to improve living standards and to stimulate an increase in the birth rate. It has also been suggested that the principle of financing child benefit through a payroll deduction be abandoned. In most transition countries children are particularly vulnerable to poverty ${ }^{2}$ so the principle of a child allowance is desirable. It is also probably desirable to focus upon children in poorer families. But the experience of many countries shows that such child allowances are ineffective at raising birth rates and any hope that they will do so in Croatia should be abandoned. They should be seen first and foremost as an anti-poverty measure and not as an instrument of pro-natalist policy. Finally, if they are to serve as an anti-poverty measure, the British experience suggests that they should be made payable explicitly to the mother and not to the family - or the father. In this way they are more likely to be used to improve children's welfare.

\section{An assessment of the presently system}

The basic structure of social assistance - as set out in of the three main forms of cash transfer contained in the new Law on Social Welfare (together with the provisions nursing and home care allowances) - provides a system that is both relatively simple and one that is comprehensive in that it is able to respond to the range of demands likely to be placed upon it. It incorporates some form of income test and this should serve to focus resources upon those most in need. In principle, therefore, it provides an appropriate component of the social safety net that is needed to make the

26 See for example, C. Grootaert and J Braithwaite The Determinants of Poverty in Eastern Europe and the Former Soviet Union (mimeo) World Bank, Washington DC, 1998; p. 62ff. 
transition to a market economy as smooth as possible. It is complemented by two categorical programmes, child allowances and unemployment compensation, which provide added protection against two major causes of poverty. (The other components-which help to insure the population against the risks that are an inevitable consequence of life in such a system - are the pension system which protects against penury in old age and the system which pays for healthcare. Neither of these forms part of the terms of reference of this report.)

The social assistance programmes introduced by the new Law on Social Welfare have many desirable features in theory. But, given the available evidence, it is not possible to determine how efficiently they operate. It is only on the basis of a family budget survey - or a special-purpose survey of the level and structure of household incomes - that it would be possible to assess both how far social assistance is concentrated on households who are poor and how far such assistance helps them to escape from poverty. That is, for Croatia, the data needed to calculate both horizontal and vertical efficiency are lacking. Until they become available, a final judgement on the system must be deferred.

There is one further comment to be made about the system of allowances introduced in the new Law on Social Welfare and, in particular the Assistance for Maintenance programme. As it is presently structured, for families receiving assistance, any increase in earnings will result in an equal reduction in benefit. That is, such families face a 100 percent marginal tax rate on earnings over the range covered by the scale in Table 9 . This certainly constitutes a disincentive to seek employment (or, possibly, to seek it in the formal sector.) It thus threatens to create a poverty trap. It is possible, however, that the SM and the scale based upon it is so low (as claimed by the Trade Unions and many observers) that few people will be caught in it. Nevertheless, it would be better to modify the scheme so as to introduce a tapered withdrawal and thus reduce the implicit marginal tax rate.

\section{Conclusion}

There are three components to Croatia's social welfare policy broadly understood. These are the pension system, the health-care and educational systems and, possibly the provision of social housing. Third, there are programmes of social insurance and social assistance. The pension system is intended to allow individuals to redistribute income over the life cycle and thus to guard against penury in old age — or as a result of disability. The health-care and educational systems (and public housing) provide access to goods and services whose supply is often characterised by market failure and significant externalities. They are intended to allow people to insure against both the risk of ill-health and the financial consequences of coping with sickness. Both the educational system 
and public or social housing contribute to social integration and compensates for failures in the capital market. Finally, social insurance and social assistance provide some protection against the (often uninsurable) risks that attend life in a market economy. On the one hand, they are an expression of social solidarity but they are also intended to make markets more flexible and thus to improve both the equity and efficiency of the economy.

The social insurance and social assistance component of social welfare policy itself consists of three, or possibly four, components. There are cash transfers. In Croatia, these include such programmes as Assistance for Maintenance, pomoć za uzdržavanje, which is intended to alleviate poverty. But they also include unemployment compensation and child benefit which are designed to provide help for individuals or families facing particular risks or encountering an additional burden. Second, there are benefits in kind; so far as the Law on Social Welfare is concerned, these are neither extensive nor substantial. Third, social welfare policy includes a more or less extensive provision of foster-care or residential care for vulnerable groups. To this list, perhaps one should add what are often known as personal social services-counselling and assistance in resolving difficulties experienced by vulnerable individuals, families or whole social groups. In this report, we have been concerned primarily with the structure and performance of this third component of Croatia's social welfare policy.

This assessment should be set in the context of the recent macro-economic performance of the republic and of the government's objectives for the country's reconstruction and further economic development. Although recent economic performance has, on the whole been satisfactory, Croatia faces more demands than many former socialist states. Both the demands of transition and of postwar reconstruction call for an increase in the level of investment. This, in turn, implies a need to raise the domestic savings rate and, possibly to attract resources from abroad. This objective imposes limits on the type and scale of social programmes that can be adopted at the present time. It is desirable, if not essential to create "space" for the investment necessary for reconstruction and further economic development. It should not be "crowded out" by public (and public current) expenditure. Yet, as the figures given earlier in this report show, this appears to be what has happened in recent years: the public sector (already large compared to other transition economies at a similar level of development) has increased further; within the public sector, current spending on social programmes-particularly pensions and health-care have also expanded absolutely and relatively. This report has sought to identify ways in which recent growth in social assistance programmes can be contained - and possibly reversed and, second, to assess whether the efficiency of welfare policy might be enhanced. 
It is possible to specify a second objective for social and economic policy in Croatia at the present time that also affects the way in which the programmes discussed in this report. In Croatia as in almost all other countries a primary aim of policy must be to get people into work-or back into work. For most people most of the time, dependency on state assistance cannot provide a satisfactory alternative to employment-either in terms psychological satisfaction or material wellbeing. We would add two further qualifications to this objective: in Croatia, it is desirable, wherever possible, that people are found (or find themselves) jobs in the formal sector. Not only are such jobs more secure, in general, they also offer more opportunities for training and the acquisition of skills. Further, they will increase the tax base and, in some measure allow a reduction in indirect labour costs. Second, in Croatia as in many other transition economies, particular attention should be paid to skills and qualifications, because the labour force is under-skilled or, more properly, inappropriately skilled for the activities that make up a modern industrial economy. This means that the investment upon which economic reconstruction and development depends should be understood to include investment in human as well as physical capital. The various elements of social welfare policy should be assessed with these goals in mind.

Some of the implications for social policy have already been mentioned earlier in the report. But we will repeat them here. First, if participation rates are to be raised, an effort should be made to reduce the indirect costs of employment. This almost certainly involves a reduction in the overall level of payroll deductions. On the one hand, it may be possible to finance some of the programmes currently paid for out of payroll taxation from alternative revenue sources; if not, it may be worth considering reductions in the level of services provided. In any case a determined effort should be made to reduce deductions to some 20-25 percent - the lower end of the range found in OECD countries.

A reduction in the indirect costs of labour should make job-creation more attractive for employers in the formal sector; it may also persuade some currently operating in the grey economy to switch to the formal sector. After all, there are benefits as well as costs to entrepreneurs from operating in the official economy. The objective should be to tilt the balance somewhat more towards the formal sector. This has two further implications, neither of which is strictly concerned with social policy. First, while payroll deductions are an important source of indirect labour costs, they are not the only one. It may be desirable to look at other sources of cost and to ask how far they might be reduced. Also, one might extend this review to non-financial sources of labour-market inflexibility, since they too add to cost and may discourage job-creation. Second, more generally, since what is required is a higher rate of job creation, one should be concerned with the buoyancy of the enterprise- and particularly the private and small business sector. If entrepreneurs are to be encouraged to expand 
and, in particular to expand in the formal economy, it is desirable to create a business-friendly environment. In this context, it is desirable to re-examine regulatory regimes, procedural tax codes and so on.

There is also scope for so-called active labour-market policies. At one end of the spectrum, these include education and training. It could be argued that such training should concentrate on those aged 15-24 years of age where unemployment rates are highest (and, possibly, the payoff to investment in human capital is greatest.) But such policies should be monitored to ensure that they are cost-effective; that is, that the benefits exceed the costs - and that the return is higher than in alternative uses of the resources. Second, for the most part, training programmes should be demandled.

As we have already pointed out, the current Assistance for Maintenance, pomoć za uzdržavanje, scheme involves very high implicit marginal rates of tax. It therefore risks creating an unemployment - and hence a poverty - trap. It would be desirable, therefore, to modify the scheme so as to taper the withdrawal of assistance and thus reduce the marginal rate of taxation involved. More generally, if one wishes to tackle the problem of low pay, it might be worth considering to introduction of assistance similar to the so-called working family's credit provided by the United Kingdom. Such a scheme is intended to make work more attractive that dependence on state benefits. It is payable only to families on low income who are in work-and in Croatia one might restrict that further to require potential beneficiaries to demonstrate that they are working in the formal sector.

The other side of the coin of encouraging employment is that social assistance should be focused on those least able to support themselves. The benefit programmes contained in the law on Social Welfare mainly incorporate an income test in addition to one or other categorical condition of entitlement. In principle this is desirable, particularly where resources are limited. But there are certain caveats that need to be borne in mind. First, if income-testing is to be credible, it requires some level of verification. Such verification involves high administrative costs. Second, it can lead to substantial social exclusion-particularly among the low-paid. More generally, as already mentioned, income tests often create disincentive effects. As a result, income-testing may be counter-productive.

In the longer term, an alternative to income testing may be the provision of so-called categorical benefits where entitlement to assistance depends upon the presence of an easily verified characteristic which has been shown to correlate highly with poverty-for example unemployment 
or the presence of several children in the family. But such programmes depend upon statistical analysis to identify the relevant factors or causes of poverty. Such analysis cannot be undertaken for Croatia until the Family Budget Survey or some other source of appropriate data becomes available.

As was observed earlier in this report the institutional framework within which social welfare policy is implemented is quite fragmented. We believe that some improvement in efficacy would follow from a rationalisation of the system. First, the so-called extra-budgetary funds should be brought more explicitly within the public finance system. (That is, they should lose their extra-budgetary status.) Second, we would suggest that the Child Benefit Fund disappear altogether and responsibility for this programme be transferred to the Ministry of Labour and Social Welfare. Third, an attempt should be made to eliminate the duplication of forms of assistance. For example, the assistance for work training and earning a living should be transferred from the MLSW to the employment service. It should probably be phased out altogether-or merged with other training and retraining programmes. Further, there is a case for some re-organisation of provision for the disabled.

Finally, we recommend that some effort be invested in improving the quality, range and frequency of social statistics. Such information is required for social planning, for the formulation of appropriate policies. One can go further, such information should also be made available to the research community and, at least in part, it should be published. These two steps will help to make government at all levels more accountable to the electorate, by providing voters with more information about the impact of government policies. They should also raise the quality of public debate and improve the quality of policy advice. 


\section{REFERENCES:}

Bejaković, P. (1998): Welfare Policy and Social Transfers in the Republic of Croatia (mimeo) Zagreb.

Bićanić, I. - Ott, K.(1997): The Unofficial Economy in Croatia: Causes, Size and Consequences, Occasional Paper No. 3, Institute of Public Finance, Zagreb.

Državni zavod za statistiku (1998): Priopćenje Državnog zavoda za statistiku Republike Hrvatske, Zagreb, 12. February 1998.

Državni zavod za statistiku (1998a): Statistical Yearbook 1998, Zagreb.

Government of the Republic of Croatia (1998): National Employment Policy, Zagreb.

Grootaert, C. - Braithwaite, J. (1998): The Determinants of Poverty in Eastern Europe and the Former Soviet Union (mimeo) Washington DC : World Bank.

Hrvatski zavod za zapošljavanje (1996, 1997): Annual Report, Zagreb.

PlanEcon Report (1998): Croatian Economic Monitor, No. 7-8.

Rutkowski, J. (1996): Changes in Wage Structure During Economic Transition in Central and Eastern Europe World Bank Technical Paper No. 340 (Social Challenges of Transition Series) Washington, DC.

Rutkowski, M. (1996a): Labour Market Policies in Transition Economies, Moct-Most, vol 6, no.1, p.19-26.

UNHDP (1997): Human Development Report: Croatia, Zagreb.

World Bank (1997): Croatia: Beyond Stabilisation, Washington DC. 
Table 1

The Structure of Public Expenditure: Croatia, 1995-1998

million kunas

\begin{tabular}{l|rrrr}
\hline & \multicolumn{1}{|c}{1995} & \multicolumn{1}{c}{1996} & \multicolumn{1}{c}{1997} & $1998^{a}$ \\
\hline State Budget & 32868 & 37463 & 42474 & $41200^{\mathrm{b}}$ \\
o/w National & 28476 & 30973 & 34393 & $33363^{\mathrm{c}}$ \\
$\quad$ Counties & 534 & 797 & 860 & $\mathrm{na}$ \\
$\quad$ City/municipal & 3858 & 5693 & 7219 & $\mathrm{na}$ \\
Extra-budgetary funds & 17977 & 21282 & 25522 & 27042 \\
o/w Pension Fund & 8860 & 10460 & 13759 & 14182 \\
$\quad$ Health Insurance Fund & 7083 & 8357 & 8743 & 9622 \\
Employment Fund & 446 & 676 & 714 & 764 \\
Child Benefit Fund & 821 & 853 & 1004 & 1122 \\
Public Water Fund & 766 & 935 & 1267 & 1334 \\
Total Public Expenditure & 50845 & 58745 & 67996 & 68241 \\
GDP & 94564 & 103610 & $109926^{\mathrm{d}}$ & \\
Public Expenditure as percent of GDP & 55.8 & 56.7 & 61.8 & \\
\hline Sorces: Es
\end{tabular}

Sources: Estimates of the Ministry of Finance; Row (12) Croatia: Beyond Stabilisation World Bank, Washington DC, 1997, p. 111.

According to the Ministry of Finance estimate on official CBS data GDP was 107.255 mil. HRK in 1996, 122.904 mil. HRK in 1997, and 135.645 in 1998. - Monthly Statistical Review of the Ministry of Finance, No. 42, April 1999, Zagreb.

Notes:

a. entries refer to projected expenditures in the relevant budget.

$b$. estimated on the basis of the relationship between national and sub-national budgets in 1997.

$c$. budgeted expenditure may differ from out-turn; it appears to have done so in previous years.

$d$ extrapolated.

Table 2

The Level of General State Social Expenditure: Croatia, 1995-1997

\begin{tabular}{|l|r|r|r|r|r|r|}
\hline & \multicolumn{2}{|c|}{1995} & \multicolumn{2}{c|}{1996} & \multicolumn{2}{c|}{1997} \\
\hline & & percent & & percent & & percent \\
\hline Total & 32868 & 100 & 37463 & 100 & 42474 & 100 \\
\hline o/w Social & 7318 & 22.3 & 9213 & 24.6 & 11922 & 28.1 \\
\hline \multicolumn{1}{|c|}{ Education } & 3916 & 11.9 & 4354 & 11.6 & 4896 & 11.5 \\
\hline \multicolumn{1}{|c|}{ Health } & 119 & 0.4 & 215 & 0.5 & 250 & 0.6 \\
\hline $\begin{array}{l}\text { Social Security \& } \\
\text { Welfare }\end{array}$ & 3283 & 10.0 & 4644 & 12.4 & 6776 & 16.0 \\
\hline $\begin{array}{l}\text { Housing \& Com. } \\
\text { Services }\end{array}$ & 2300 & 7.0 & 4353 & 11.6 & 4473 & 10.5 \\
\hline Other & 23250 & 70.7 & 23898 & 63.8 & 26079 & 61.4 \\
\hline
\end{tabular}

Source: Compiled from Ministry of Finance Data 
Table 3

Composition of General Social Expenditure: Croatia, 1997

\begin{tabular}{l|rrrr}
\hline & \multicolumn{1}{|c}{ Total } & National & County & \multicolumn{1}{c}{ City } \\
\hline Total Expenditure (m. kunas) & 42474 & 34395 & 860 & 7219 \\
(percent) & 100.0 & 81.0 & 2.0 & 17.0 \\
o/w Social & 28.1 & 31.1 & 23.0 & 14.3 \\
$\quad$ Education & 11.5 & 11.8 & 5.5 & 11.0 \\
Health & 0.6 & 0.5 & 4.0 & 0.4 \\
Soc. Security & 16.0 & 18.8 & 13.5 & 2.9 \\
Housing \& Com. Services & 10.5 & 6.0 & 7.3 & 32.4 \\
Other & 61.8 & 62.9 & 69.7 & 53.3 \\
\hline
\end{tabular}

Table 4

Composition of Central Government Tax Revenue: Croatia, 1997

\begin{tabular}{l|rr}
\multicolumn{2}{c}{ percent } \\
\hline Total Tax Revenue & Total Tax Revenue & GDP \\
Direct taxes & 100 & 43.2 \\
o/w Payroll Deductions & 47.6 & 20.6 \\
Personal Income Tax & 37.4 & 16.2 \\
Corporate Income Tax & 6.8 & 2.9 \\
Other & 3.1 & 1.3 \\
Indirect Taxes & 0.4 & 0.2 \\
Domestic & 52.4 & 22.6 \\
Trade & 43.5 & 18.8 \\
\hline
\end{tabular}

Croatia: Beyond Stabilisation, World Bank, Washington, DC, 1997; p. 88.

Table 5

Demographic Structure: Croatia, 1996-1997

\begin{tabular}{l|rrr|rrr}
\hline & \multicolumn{3}{|c|}{1996} & \multicolumn{1}{c}{ 1997 } & 000 \\
\hline & Males & Females & Total & Males & Females & Total \\
Total Population & 1794 & 1958 & 3752 & 1906 & 2079 & 3984 \\
o/w -15yrs & 366 & 344 & 710 & 383 & 369 & 751 \\
$\quad$ working age & 1428 & 1614 & 3042 & 1523 & 1710 & 3233 \\
$(15+)^{*}$ & & & & & & \\
o/w active & 927 & 784 & 1711 & 954 & 814 & 1768 \\
$\quad$ employed & 838 & 702 & 1540 & 864 & 729 & 1593 \\
$\quad$ unemployed & 88 & 82 & 170 & 91 & 84 & 175 \\
inactive & 501 & 830 & 1331 & 568 & 896 & 1464 \\
\hline
\end{tabular}

Source: Priopćenje Državnog Zavoda za Statistiku Republike Hrvatske, Zagreb 12 February 1998, p.2

* In the LFS, the population of working age is defined as from 15 to 85 years of age. 
Table 6

Age and Sex-Specific Participation Rates: Croatia, 1997

\begin{tabular}{l|crrr}
\hline & \multicolumn{3}{|c}{ Employment $^{a}$} & \multicolumn{3}{c}{ Participation $^{b}$} \\
\hline & Males & Females & Males & Females \\
15-24 years & 31.7 & 30.1 & 44.3 & 41.0 \\
25-49 years & 82.9 & 71.2 & 89.4 & 78.1 \\
50-64 years & 49.9 & 27.4 & 52.5 & 28.8 \\
65-85 years & 16.4 & 9.4 & 16.6 & 9.5 \\
85+ years & 7.1 & 2.0 & 7.1 & 2.0 \\
Total & 56.9 & 42.7 & 62.7 & 47.6 \\
\hline
\end{tabular}

Source: Priopćenje Državnog Zavoda za Statistiku Republike Hrvatske Zagreb 12 February 1998, p. 3

Notes: $a$. the employed population as a percent of the total population of a given age and sex.

$b$. the active population (employed + unemployed) as a percentage of the total population of given age and sex.

Table 7

The Structure of Unemployment: Croatia, 1997

\begin{tabular}{|c|c|c|c|c|c|c|}
\hline & \multicolumn{3}{|c|}{ Unemployment Rates } & \multicolumn{3}{|c|}{ Share of Unemployment } \\
\hline & Males & Females & Total & Males & Females & Total \\
\hline $15-24$ yrs & 29.9 & 26.9 & 26.5 & 20.6 & 17.1 & 37.7 \\
\hline $25-49$ yrs & 7.3 & 8.8 & 8.0 & 26.3 & 28.0 & 54.3 \\
\hline $50-64$ yrs & 4.8 & 4.4 & 6.0 & 4.6 & 2.8 & 7.4 \\
\hline $65-85 \mathrm{yrs}$ & $(1.1)$ & (1.1) & 1.1 & $(0.5)$ & $(0.1)$ & 0.6 \\
\hline Total & 9.5 & 10.4 & 9.9 & 52.0 & 48.0 & 100 \\
\hline
\end{tabular}

Source: Priopćenje Državnog Zavoda za Statistiku Republike Hrvatske Zagreb 12 February 1998, p.4

Table 8

Duration of Unemployment: Croatia, 1997

\begin{tabular}{|c|c|c|c|}
\hline & Males & Females & Total \\
\hline up to 1 Month (and those who have found jobs) & $(12)$ & $(9)$ & $(21)$ \\
\hline $1-3$ months & (12) & (10) & 22 \\
\hline 4-6 Months & (10) & (11) & 20 \\
\hline 7-12 Months & 19 & 16 & 34 \\
\hline 13-24 Months & 18 & 14 & 33 \\
\hline 25+ Months & 20 & 25 & 45 \\
\hline Total & 91 & 84 & 175 \\
\hline
\end{tabular}

Source: Priopćenje Državnog Zavoda za Statistiku Republike Hrvatske Zagreb 12 February 1998, p.11 
Table 9

Social Minimum: Croatia, 1995-1998

kunas per month

\begin{tabular}{l|rrrr}
\hline & \multicolumn{1}{|c}{$\begin{array}{c}\text { January } \\
1995\end{array}$} & $\begin{array}{c}\text { January } \\
1996\end{array}$ & $\begin{array}{c}\text { January } \\
1997\end{array}$ & \multicolumn{1}{c}{$\begin{array}{c}\text { January } \\
1998\end{array}$} \\
\hline Social Minimum Allowance & & & & \\
1-member household & 234 & 243 & 315 & 350 \\
2-member household & 416 & 432 & 560 & $630-700^{\mathrm{a}}$ \\
3-member household & 572 & 594 & 770 & $910-1050^{\mathrm{a}}$ \\
4-member household & 702 & 729 & 945 & $1190-1400^{\mathrm{a}}$ \\
each additional member & 78 & 81 & 105 & $280-350^{\mathrm{a}}$ \\
\hline
\end{tabular}

Source: Compiled from data supplied by the Croatian Ministry of Labour and Social Welfare.

${ }^{a}$ In 1998 the principle on which the social minimum was calculated was changed. From this date, the SM is set at 350 kuna per month for the first adult or for children between the ages of 15 and 18 years, 280 kuna for each additional adult and for children under the age of 7 years and 315 kuna for children between the ages of 7 and 15 years. The ranges cited in that table reflect minima associated with alternative possible family compositions.

Table 10

The Evolution of Earnings: Croatia, 1995-1998

\begin{tabular}{l|rr}
\hline & $\begin{array}{c}\text { Nominal Net Wage } \\
\text { (Enterprise Sector) } \\
\text { kunas }\end{array}$ & $\begin{array}{c}\text { Real Net Wage } \\
\text { (Enterprise Sector) } \\
\text { 1993=100 }\end{array}$ \\
\hline June 1995 & 1735 & 151.8 \\
December 1995 & 1826 & 153.5 \\
June 1996 & 2036 & 162.2 \\
December 1996 & 2177 & 170.9 \\
June 1997 & 2329 & 186.4 \\
November 1997 & 2450 & 187.7 \\
February 1998 & 2475 & 189.6 \\
\hline
\end{tabular}

Sources: Rows (1)-(6) PlanEcon Report: Croatian Economic Monitor, March 19, 1998; p. 23. Row (7) Source: Priopćenje Državnog zavoda za statistiku Republike Hrvatske, Zagreb, 4. May 1998; p. 2.

Table 11

The Distribution of Wages ${ }^{a}$ : Croatia, 1996-1998

\begin{tabular}{|l|r|r|r|}
\hline & December & December & March \\
& 1996 & 1997 & 1998 \\
\hline Median wage (kunas) & 1958.0 & 2305 & 2253 \\
$1^{\text {st }}$ Decile (as percent of median) & 57.6 & 57.0 & 59.6 \\
$1^{\text {st }}$ Quartile & 78.3 & 76.1 & 76.1 \\
$3^{\text {rd }}$ Quartile & 131.6 & 130.9 & 127.8 \\
$9^{\text {th }}$ Decile & 152.2 & 164.7 & 150.0 \\
$\mathrm{~d}_{9} / \mathrm{d}_{1}$ & 2.6 & 2.9 & 2.5 \\
\hline
\end{tabular}

Source: calculated from figures supplied by the Institute of Finance.

$a$ The figures refer to the distribution of workers by net wages in both the productive, privreda, and the unproductive, neprivreda, sectors. In all probability the private sector is underrepresented. 
Table 12

Registered Unemployment and Unemployment Benefit: Croatia, 1995-1997

\begin{tabular}{|l|r|r|r|}
\hline & \multicolumn{1}{|c|}{1995} & \multicolumn{1}{|c|}{1996} & \multicolumn{1}{|c|}{1997} \\
\hline Registered Unemployment (monthly average) & 255230 & 276290 & 277691 \\
Beneficiaries (monthly average) & 36183 & 52912 & 55171 \\
Share (in percent) & 14.2 & 19.2 & 19.9 \\
Aggregate Expenditure on Benefit (m kunas) & 268.5 & 427.0 & $545.6^{\mathrm{a}}$ \\
Average Monthly Benefit (kunas) & 618.4 & 672.5 & $733.4^{\mathrm{b}}$ \\
\hline
\end{tabular}

Source: calculated from information supplied by the State Employment Service.

${ }^{\text {a }}$ Forecast level of expenditure; for expenditure as a whole, the realised level was approximately 89 percent of the forecast.

b adjusted for the fact that out-turn was less than forecast. Without this adjustment, the average monthly benefit was estimated at 824 kunas.

Table 13

Social Welfare and Social Assistance: Croatia, 1995-1997

\begin{tabular}{|l|r|r|r|r||r|}
\hline & \multicolumn{1}{|c|}{1995} & \multicolumn{1}{|c|}{1996} & \multicolumn{2}{c|}{1997} & \multicolumn{2}{|c|}{1997} \\
\hline & \multicolumn{2}{|c|}{ m. kunas } & & $\begin{array}{r}\text { percent } \\
\text { total of }\end{array}$ & $\begin{array}{c}\text { percent of } \\
\text { category }\end{array}$ \\
\hline Cash Benefits (1.1-1.12) & $\mathbf{2 0 3 . 8}$ & $\mathbf{2 2 0 . 0}$ & $\mathbf{2 7 8 . 6}$ & $\mathbf{2 9 . 8}$ & $\mathbf{1 0 0 . 0}$ \\
1.1 Financial Assistance & 28.9 & 31.9 & 40.9 & & 14.7 \\
1.3 Non-Recurring assistance & 23.2 & 28.4 & 36.0 & & 12.9 \\
1.5 Allowance for Nursing and Home & 18.4 & 21.0 & 31.0 & & 11.1 \\
Care & & & & & \\
1.7 Subsidy for Social Minimum & 110.0 & 109.1 & 136.7 & & 49.0 \\
1.10 Right to Reduced Working time & 14.6 & 20.3 & 22.8 & & 8.2 \\
for parents of Handicapped Children & & & & & \\
Other & 8.6 & 9.2 & 11.1 & & 4.0 \\
Assistance in Kind (2.1-2.6) & $\mathbf{5 4 . 7}$ & $\mathbf{3 5 . 3}$ & $\mathbf{4 1 . 6}$ & $\mathbf{4 . 4}$ & $\mathbf{1 0 0 . 0}$ \\
2.2 Assistance with Heating Fuel & 7.2 & 6.9 & 6.8 & & 16.3 \\
2.5 Free Schoolbooks & 24.5 & & & & \\
2.6 Financial Assistance in paying for & 20.6 & 25.8 & 30.9 & & 74.2 \\
Public and Communal Services & & & & & \\
Other & 2.4 & 2.6 & 4.0 & & 9.6 \\
Residential Care and Fostering & $\mathbf{4 6 6 . 4}$ & $\mathbf{5 3 3 . 2}$ & $\mathbf{6 4 4 . 3}$ & $\mathbf{6 9 . 0}$ & $\mathbf{1 0 0 . 0}$ \\
3.4 Fostering & 19.9 & 36.9 & 53.4 & & 8.3 \\
5.6 Residential Care & 224.5 & 468.1 & 509.1 & & 79.0 \\
7.8 Other & 22.1 & 28.2 & 81.8 & & 12.7 \\
Total Expenditure & $\mathbf{7 2 5 . 0}$ & $\mathbf{7 8 8 . 5}$ & $\mathbf{9 3 3 . 7}$ & $\mathbf{1 0 0 . 0}$ & \\
\hline
\end{tabular}

Sources: Compiled from data provided by the Ministry of Labour and Social Welfare and the Institute of Public Finance.

${ }^{a}$ Since 1996, free schoolbooks for primary school pupils of socially threatened families have been provided by the Ministry of Education and Sport. 
Table 14

Number of Beneficiaries of Welfare Programmes: Croatia, 1995-1997

\begin{tabular}{l|rrr}
\hline & \multicolumn{3}{c}{000} \\
\hline Cash Benefits (1.1-1.12) & 1995 & 1996 & \multicolumn{1}{c}{1997} \\
1.1 Financial Assistance & 13.8 & $\mathbf{1 7 5 . 0}$ & $\mathbf{1 9 6 . 9}$ \\
1.3 Non-Recurring Assistance & 80.9 & 12.9 & 13.6 \\
1.5 Allowance for Nursing and Home-care & 13.3 & 14.8 & 102.1 \\
1.7 Subsidy for Social Minimum & 50.6 & 45.9 & 53.4 \\
1.10 Right to Reduced Working Time for Parents of & 1.4 & 1.6 & 2.1 \\
$\quad$ Handicapped Children & & & \\
Other & 10.5 & 7.5 & 7.9 \\
Assistance in Kind (2.1-2.6) & $\mathbf{2 3 5 . 5}$ & $\mathbf{1 4 1 . 4}$ & $\mathbf{1 2 4 . 6}$ \\
2.2 Assistance with Heating & 6.5 & 7.8 & 7.3 \\
2.5 Free Schoolbooks & 121.6 & & \\
2.6 Financial Assistance in Paying for Public and & 102.0 & 124.8 & 105.7 \\
$\quad$ Communal Services & & & \\
Residential Care and Fostering (3-8) & $\mathbf{1 2 . 8}$ & $\mathbf{1 2 . 7}$ & $\mathbf{1 4 . 3}$ \\
3.4 Fostering & 2.7 & 3.1 & 3.6 \\
5-6 Residential Care & 9.7 & 9.4 & 10.4 \\
Other & 0.4 & 0.2 & 0.3 \\
Total Number receiving Assistance & $\mathbf{4 1 8 . 2}$ & $\mathbf{3 2 9 . 3}$ & $\mathbf{3 3 5 . 9}$ \\
\hline
\end{tabular}

Source: Ministry of Labour and Social Welfare. 